Bovgyria I.V., PhD. student, department of Sociology National University Kyiv-Mohyla Academy, 2, Skovorody Str., Kyiv, 04070, Ukraine, e-mail: iryna.bovgyria@gmail.com

\title{
CONSIDERING ONESELF (NON)RELIGIOUS IN EASTERN EUROPEAN SOCIETIES: CORRELATION PATTERNS AMONG RELIGIOSITY DIMENSIONS
}

\begin{abstract}
While a number of current studies of religion are based on the religiosity dimension approach, in most cases, this approach is used only as a structural base for choosing an investigation level. At the same time, multidimensional approach can help us understand which combinations of religious manifestations are associated with self-identification as a religious person. The article presents analysis of empirical data with the aim to evaluate how various religiosity dimensions are related to identifying oneself as religious or non-religious and to investigate respective correlation differences in terms of direction and intensity in societies of Eastern Europe. It presents a comparative analysis of EVS survey results from 19 countries of Eastern Europe. It shows that, while all of the countries within the region have statistically significant positive correlations between religiosity dimensions and considering oneself (non)religious; correlation strengths differ so significantly that it is difficult to claim about unified pattern across all Eastern European societies. Comparative analysis of archived results allows to identify several clusters of countries within the region with common patterns in intensity of correlation between religiosity dimensions and considering oneself (non)religious. The differences in correlation profiles might be caused by historical and cultural background of the counties, their denominational structure and share of persons who consider one selves religious, character of cultural concept of 'a religious person' and linkage of religious identification with other identities in society.
\end{abstract}

Keywords: religiosity, sociology of religion, religion in Eastern Europe, religion in post-communist societies, dimensions of religiosity.

Introduction. Self-identification as a 'religious' or 'non-religious' person is a multidimensional attribution. On detailed consideration, there are neither strict nor universal criteria of identifying with either of these groups. Some researchers point out that religiosity as a defining characteristic is part of a culture and thus reflects current social understanding of 'being a religious person' $[1$, p. $69-73 ; 2$, p. 3]. Respectively, we can assume that any socio-cultural change may affect conceptual models of religiosity in each particular society. A lot of current studies of religion are based on the approach of dimensions of religiosity initially proposed by Gerhard Lenski and further developed by other scientists, such as Glock (1962), King (1967), Verbit (1970), O'Connel (1975) and others [3, p. 60-65]. However, in most cases, this approach is used as a structural base for investigation levels or as a base for religiosity index construction without investigation of interrelations between dimensions $[4$, p. $34 ; 5$, p. $111 ; 6$, p. 171-172]. In other words, investigators rarely aim to build a multidimensional picture of religiosity based on empirical data and, instead, tend to evaluate different dimensions of religiosity sequentially. At the same time, multidimensional approach can help us understand which combinations of religious manifestations are associated with self-identification as a religious person. This question becomes even more important in those cases when substantial socio-cultural changes have a direct impact on the position and acceptance of religion in societies. We can designate the transition period from

(C) Bovgyria I.V., 2017 
communist to democratic regimes in Eastern Europe in the late 20th - early 21st centuries as such a case. This period is marked by eliminating severe restrictions on religious institutions, establishing religious organizations in the new environment, and integrating religion into national identity that, in many cases, contributed to legitimization of new regimes [7, p. 229248]. The combination of all these circumstances presumably yielded to emergence of a different conceptual understanding of 'a religious person' in the societies of the region. This article aims to evaluate how various religiosity dimensions are related to identifying oneself as religious or non-religious and to investigate respective correlation differences in societies of Eastern Europe. This goal can be reached through answering the following questions: Are there any significant correlations between key religiosity dimensions and considering oneself (non)religious? Do the intensity and direction of correlations differ in various socio-cultural environments? And are there any patterns in correlation profiles for countries with similar historical and cultural background?

Conceptual framework. Proceeding from the idea that religiosity is multidimensional and, therefore, one cannot reduce the manifestations and impact of religion to a single variable, the proposed investigation will be focused on the dimensions in the tradition of Charles Glock, further revised by other investigators. Glock (1962) and later Glock and Stark (1965) suggested a framework of religiosity that consists of 5 dimensions: 'the experiential', 'the ritualistic', 'the ideological', 'the intellectual', and 'the consequential' $[8,9]$. According to Glock, the 'experiential dimension' of religiosity refers to religious emotions. The 'ideological dimension' gives recognition to certain beliefs, to which followers are expected to adhere. The 'ritualistic dimension' includes specific religious practices expected of religious followers. The 'intellectual dimension', in Glock's framework, is constituted by the expectation that the religious person should have some knowledge about the basic tenets of his/her faith. The 'consequential dimension' uncovers the appearance of religion in everyday life [8, p. 98-110]. Further investigations of the religiosity dimensions were centered on testing and amplifying these dimensions. King (1967), Verbit (1970), and O'Connel (1975) suggested some additional dimensions to the framework initially proposed by Glock $[10,11,12]$. Still, all their suggestions can be classified as extra sub-dimensions conceptually related to the dimensions already introduced [3, p. 63].

Nevertheless, the initial framework proposed by Glock has a significant limitation for cross-cultural testing, considering the importance of maintaining comparable indicators for different cultures and religions. To overcome this limitation, we shall use the approach suggested by Olaf Muller. According to Muller, such dimensions of religiosity as identification, praxis, experience and faith relate not only to Christianity but also to nonChristian and extra-ecclesiastical forms of religiosity [4, p. 34-36]. In Olaf Muller's specification, the identification dimension addresses the questions of who belongs to a religious community, identifies with a religion or denomination, joins or leaves a religious community and feels connected with it. The second dimension - praxis - refers to rites and cultic performances that frequently constitute the backbone of a religion. The dimension of religious experience and faith is depicted in terms of belief in God or other significant doctrinal aspects and religious experience [4, p. 34-36]. Muller's classification can be 
applied to construct indicators of religiosity dimensions using key cross-cultural survey datasets on religiosity.

Method, data and empirical indicators. The key focus of the proposed study (i.e. the evaluation level of connection between religiosity dimensions and identification as religious or non-religious) is based on quantitative comparative analysis of data from the European Values Survey 2008 [13; 14]. The key deliverables are based on descriptive data and simple bivariate analysis. This dataset was previously used by Ukrainian sociologists for other research goals and respectively other conceptual and methodological tools were applied $[15 ; 16]$.

The empirical part contains survey results from 19 countries of Eastern Europe that were under the communist rule in the 20th century. The latest survey data were chosen to omit the most dynamic transition period in the region, when, presumably, the social understanding of a 'religious person' was under construction, and some of its characteristics reflect situational features rather than an established pattern ${ }^{1}$. According to this specification, the survey sample covers micro-level results from Poland, Slovakia, Croatia, Lithuania, Slovenia, Hungary, the Czech Republic, Latvia, Estonia, East Germany, Romania, Bulgaria, Serbia, Moldova, the Russian Federation, Ukraine, Bosnia- Hercegovina and Albania.

Following the recommendation made by S. Salnikova in her overview "Methodological Foundations of Measuring Religiosity" ("Методологічні засади вимірювання релігійності"), a total representative sample was analyzed, without any additional selection of respondents based on their attitudes or self-identification with religious indicators. Such approach is regarded as the most appropriate in cases when the aim of the study is to find typologies or patterns of religiosity dimensions applicable for further comparison [17, p. 140].

A number of EVS questions were engaged to construct empirical indicators for the chosen dimensions. To measure the identification dimension, as a display of community belonging, direct question 'Do you belong to religious denomination?' (v105) was used.

The praxis dimension was divided into public and private practices. Both aspects of ritualistic manifestation were measured through the questions that indicate the frequency of such activities. Question 'Apart from weddings, funerals and christenings, about how often do you attend religious services these days?' (v109), with answers on a 7-point scale, where 1 means 'more than once a week' and 7 - 'never, practically never', was used to measure the level of involvement in the public practice. Question 'How often do you pray to God outside of religious services?' (v135), with answers on a 7-point scale, where 1 means 'every day' and 7 - 'never, practically never', was used for measurement of the private practice. The scale of answers for both questions was recoded to a reverse scale to reach unidirectionality of all the scales in the analysis.

The dimension of religious experience and faith was also split into two sub-dimensions: experience and faith, respectively. To determinate a measurement for the religious

\footnotetext{
${ }^{1}$ WVS 2014 is the latest available international open access survey dataset that contains some data on religiosity (including Eastern Europe). However, it contains very few questions about religious views and practices. Moreover, it does not contain the following questions crucial for this investigation: 'How religion is important in your life?' and 'Do you find that you get comfort and strength from religion or not?'. Thus, the latest data that contains a full list of variables, necessary for this analysis is EVS 2008.
} 
experience sub-dimension, subjective evaluation of religion's significance in one's life should be considered, including both cognitive and emotional components. Two questions ('How religion is important in your life?' (v6) and 'Do you find that you get comfort and strength from religion or not?' (v130)) were chosen to depict both components. The scale reliability test for indicators of religion importance in life and emotions connected with religion showed a reliable result (Cronbach's Alpha equals 0.74). To reduce the number of measurements, the selected variables were recombined to create a single measurement by joining positive answers into a new variable "Religious experience", where 1 means that religion is important in a respondent's life or gives comfort and strength and 0 - that none of the outcomes is relevant for the respondent ${ }^{2}$.

Choosing measures for faith sub-dimension requires attention to specifics of religious beliefs in the region: we need to find inclusive measurements, which would correspond to a variety of religious views. Thus, when looking into belief in God, both understandings of God available in the survey were included in the measurement of the faith sub-dimension (Table 1).

Another important aspect of religious faith is the possibility of continued conscious existence after death. Aggregation of relevant positive answers (belief in hell (v121), heaven (v122), life after death (v120)) allows to measure this aspect in the most inclusive way.

Since, according to the chosen approach, any aspect of religious belief can be considered as an attribute of the faith sub-dimension, belief in God (either person or spirit/life force) and belief in any type of continued conscious existence after death were combined into a single variable. This variable indicates presence or absence of at least one of these beliefs ${ }^{3}$. This approach seems to be relevant for the purpose of the survey, taking into account that, according to reliability test results, items involved in the sub-dimension construction adequately perform as a single item (Cronbach's Alpha equals 0.84).

Table 1

Belief in God, Spirit or Life Force, \%

\begin{tabular}{|l|c|}
\hline There is a personal God & 36.1 \\
\hline There is some sort of spirit or life force & 37.3 \\
\hline I don't really know what to think & 15.2 \\
\hline I don't really think there is any sort of spirit, God or life force & 11.4 \\
\hline
\end{tabular}

Sources: EVS 2008; presence of a response to "Which of these statements comes closest to your beliefs?" ("no answer" and "don't know" excluded from distribution); cumulated result (based on data from 19 countries; $n=26875)$.

\footnotetext{
${ }^{2}$ A new variable - the experience sub-dimension - was recoded by the following rule: if the importance of religion in life was pointed out (either response option 1 - 'very important' or 2 - 'quite important' was chosen to question 'How religion is important in your life?' (v6), or the positive answer (1 - "Yes") to question 'Do you find that you get comfort and strength from religion or not?' (v130) was given, the new variable was scored as 1 ; if no positive answers were mentioned to questions v130, v106, the new variable was scored -0 .

3 The Faith sub-dimension was recoded by the following rule: if the positive answer (1 - "Yes") was declared to any of questions "Do you believe in God (v119), hell (v121), heaven (v122), life after death (v120)" or alternatives "There is a personal God" or "There is some sort of spirit or life force" were chosen to question "Which of these statements comes closest to your beliefs?" (v125) the new variable was scored as 1 ; if none of the mentioned alternatives was chosen, the new variable was scored as 0 .
} 


\section{Bovgyria I.V.}

To measure identification as religious or non-religious, question 'are you a religious person' with direct wording 'Independently of whether you go to church or not, would you say you are...'(v114) was used. Question propose three key answers: 1 - 'a religious person', 2 - 'not a religious person', 3 - 'a convinced atheist', which were recoded to a dummy variable with alternatives 0 - 'not a religious person' (summarize alternatives 2 'not a religious person', 3 - 'a convinced atheist' of original question) and 1 - 'a religious person' (equal to alternative 1 - 'a religious person' of original question).

Empirical results. To build a comprehensive picture of correlations between religiosity dimensions and considering oneself (non)religious in Eastern European societies, the significance, direction and strength of correlations were examined.

As can be seen in Table 2, all the dimensions of religiosity have significant positive correlations with the identification as religious or non-religious for all the countries of the region.

Correlations of Considering Oneself (Non)Religious

Table 2

with Other Religiosity Indicators: Eastern European Countries and Territories

\begin{tabular}{|l|c|c|c|c|c|c|c|c|c|c|}
\cline { 2 - 13 } & \multicolumn{2}{c|}{$\begin{array}{c}\text { Denominational } \\
\text { identity }\end{array}$} & \multicolumn{2}{c|}{$\begin{array}{c}\text { Public } \\
\text { practices }\end{array}$} & \multicolumn{2}{c|}{$\begin{array}{c}\text { Private } \\
\text { practices }\end{array}$} & \multicolumn{2}{c|}{ Experience } & \multicolumn{2}{c|}{ Faith } \\
\cline { 2 - 13 } & $\begin{array}{c}\text { Correlation } \\
\text { coefficient }\end{array}$ & Sig. & $\begin{array}{c}\text { Correlation } \\
\text { coefficient }\end{array}$ & Sig. & $\begin{array}{c}\text { Correlation } \\
\text { coefficient }\end{array}$ & Sig. & $\begin{array}{c}\text { Correlation } \\
\text { coefficient }\end{array}$ & Sig. & $\begin{array}{c}\text { Correlation } \\
\text { coefficient }\end{array}$ & Sig. \\
\hline Albania & 0.26 & 0.000 & 0.29 & 0.000 & 0.47 & 0.000 & 0.39 & 0.000 & 0.97 & 0.000 \\
\hline $\begin{array}{l}\text { Bosnia- } \\
\text { Herzegovina }\end{array}$ & 0.36 & 0.000 & 0.34 & 0.000 & 0.36 & 0.000 & 0.49 & 0.000 & 0.84 & 0.000 \\
\hline Bulgaria & 0.46 & 0.000 & 0.42 & 0.000 & 0.60 & 0.000 & 0.58 & 0.000 & 0.52 & 0.000 \\
\hline Belarus & 0.31 & 0.000 & 0.44 & 0.000 & 0.54 & 0.000 & 0.41 & 0.000 & 0.25 & 0.000 \\
\hline Croatia & 0.53 & 0.000 & 0.45 & 0.000 & 0.51 & 0.000 & 0.59 & 0.000 & 0.50 & 0.000 \\
\hline $\begin{array}{l}\text { The Czech } \\
\text { Republic }\end{array}$ & 0.83 & 0.000 & 0.69 & 0.000 & 0.75 & 0.000 & 0.75 & 0.000 & 0.69 & 0.000 \\
\hline Estonia & 0.61 & 0.000 & 0.56 & 0.000 & 0.69 & 0.000 & 0.65 & 0.000 & 0.55 & 0.000 \\
\hline Hungary & 0.55 & 0.000 & 0.58 & 0.000 & 0.68 & 0.000 & 0.71 & 0.000 & 0.54 & 0.000 \\
\hline Latvia & 0.54 & 0.000 & 0.46 & 0.000 & 0.56 & 0.000 & 0.55 & 0.000 & 0.55 & 0.000 \\
\hline Lithuania & 0.85 & 0.000 & 0.52 & 0.000 & 0.48 & 0.000 & 0.53 & 0.000 & 0.57 & 0.000 \\
\hline Moldova & 0.34 & 0.000 & 0.29 & 0.000 & 0.36 & 0.000 & 0.38 & 0.000 & 0.29 & 0.000 \\
\hline Poland & 0.57 & 0.000 & 0.45 & 0.000 & 0.45 & 0.000 & 0.41 & 0.000 & 0.50 & 0.000 \\
\hline Romania & 0.19 & 0.000 & 0.28 & 0.000 & 0.44 & 0.000 & 0.35 & 0.000 & 0.22 & 0.000 \\
\hline $\begin{array}{l}\text { The Russian } \\
\text { Federation }\end{array}$ & 0.70 & 0.000 & 0.52 & 0.000 & 0.57 & 0.000 & 0.61 & 0.000 & 0.73 & 0.000 \\
\hline Serbia & 0.27 & 0.000 & 0.33 & 0.000 & 0.44 & 0.000 & 0.51 & 0.000 & 0.69 & 0.000 \\
\hline $\begin{array}{l}\text { The Slovak } \\
\text { Republic }\end{array}$ & 0.81 & 0.000 & 0.56 & 0.000 & 0.60 & 0.000 & 0.67 & 0.000 & 0.80 & 0.000 \\
\hline Slovenia & 0.62 & 0.000 & 0.55 & 0.000 & 0.55 & 0.000 & 0.58 & 0.000 & 0.52 & 0.000 \\
\hline Ukraine & 0.66 & 0.000 & 0.41 & 0.000 & 0.47 & 0.000 & 0.56 & 0.000 & 0.61 & 0.000 \\
\hline $\begin{array}{l}\text { East } \\
\text { Germany }\end{array}$ & 0.71 & 0.000 & 0.68 & 0.000 & 0.79 & 0.000 & 0.80 & 0.000 & 0.63 & 0.000 \\
\hline
\end{tabular}

Sources: EVS 2008; bivariate correlations; Spearman coefficient ( $\rho$ ); two-tailed significance, a separate analysis for each country ( $\mathrm{n} \geq 968$ per country); all coefficients are significant at 0.01 level. 
Key differences are in correlation strength. The most striking difference in correlation levels is observed between societies with the highest and lowest shares of people who consider themselves religious (Table 3 ).

In the most religious societies by self-identification criteria (Serbia, Albania, BosniaHerzegovina), only the faith dimension has a high correlation level with identifying oneself as religious. At the same time, in these societies, correlation with the public manifestation indicators (denominational identity, public practices) is relatively week. Presumably, such a high share of religious persons in the population of these countries is attributed to the fact that the cultural model does not put severe requirements to such self-evaluation. In the most secular societies (East Germany, Belarus, the Czech Republic) the situation looks nearly the opposite. According to the correlation results, for East Germany and the Czech Republic all the dimensions correlate heavily with consideration oneself (non)religious. It seems that involvement in all kinds of religious manifestations is an essential condition for selfattribution as a religious person in these societies.

However, correlational trends in Belarus are noticeably different from its least religious counterparts, i.e. East Germany and Czech Republic. Instead, Belarus as well as Moldova and Romania show a weak correlation of all the religiosity dimensions with considering oneself (non)religious (Table 4).

Correlations of Considering Oneself (Non)Religious with Other Religiosity Indicators:

EVS Countries and Territories with the Largest and the Smallest Shares of Those Who Consider Themselves Religious

\begin{tabular}{|c|c|c|c|c|c|c|}
\hline & \multirow{2}{*}{\multicolumn{5}{|c|}{ Correlation Coefficients for Five Dimensi }} & \multirow{3}{*}{$\begin{array}{c}\text { Considering } \\
\text { Oneself Religious, } \\
\%\end{array}$} \\
\hline & & & & & & \\
\hline & $\begin{array}{c}\text { Denominational } \\
\text { identity }\end{array}$ & $\begin{array}{c}\text { Public } \\
\text { practices }\end{array}$ & $\begin{array}{c}\text { Private } \\
\text { practices }\end{array}$ & Experience & Faith & \\
\hline \multicolumn{7}{|c|}{ Three countries with the lowest level of self-identification as religious } \\
\hline East Germany & 0.71 & 0.68 & 0.79 & 0.80 & 0.63 & 17.7 \\
\hline Belarus & 0.31 & 0.44 & 0.54 & 0.41 & 0.25 & 31.8 \\
\hline The Czech Republic & 0.83 & 0.69 & 0.75 & 0.75 & 0.69 & 33.9 \\
\hline \multicolumn{7}{|c|}{ Three countries with the highest level of self-identification as religious } \\
\hline Serbia & 0.27 & 0.33 & 0.44 & 0.51 & 0.69 & 90.2 \\
\hline Albania & 0.26 & 0.29 & 0.47 & 0.39 & 0.97 & 90.8 \\
\hline Bosnia-Herzegovina & 0.36 & 0.34 & 0.36 & 0.49 & 0.84 & 94.8 \\
\hline
\end{tabular}

Sources: EVS 2008; bivariate correlations, Spearman coefficient $(\rho)$; a separate analysis for each country ( $\mathrm{n} \geq 968$ per country), all coefficients are significant at 0.01 level; a share of responses "a religious person" to question "Independently of whether you go to church or not, would you say you are...", a separate analysis for each country ( $\mathrm{n} \geq 968$ per country).

Table 4

Correlations of Considering Oneself (Non)Religious with Other Religiosity Indicators: EVS Countries and Territories With Weak Correlation Between the Religious Dimensions and Considering Oneself (Non)Religious, correlation coefficients

\begin{tabular}{|l|c|c|c|c|c|}
\cline { 2 - 6 } \multicolumn{1}{c|}{} & Denominational identity & Public practices & Private practices & Experience & Faith \\
\hline Belarus & 0.31 & 0.44 & 0.54 & 0.41 & 0.25 \\
\hline Romania & 0.19 & 0.28 & 0.44 & 0.35 & 0.22 \\
\hline Moldova & 0.34 & 0.29 & 0.36 & 0.38 & 0.29 \\
\hline
\end{tabular}

Sources: EVS 2008; bivariate correlations, Spearman coefficient $(\rho)$; a separate analysis for each country $(\mathrm{n} \geq 968$ per country), all coefficients are significant at 0.01 level. 
A shared characteristic of these societies is that the observed dimensions of religiosity are applicable not only to those respondents who consider themselves religious (Table 5). In Belarus, only one person in three considers oneself religious (31.8\%) but, at the same time, more than half of the population manifests religiosity in some other way: $71.5 \%$ declare affiliation with some denomination, 55.5\% attend church at least several times per year, $47.9 \%$ pray at least once a month, $86.6 \%$ believe in God (or spirit / life force) or life after death. In case of Moldova and Romania, this pattern is not so striking, but it is explicit in the denominational identity and faith dimensions. Presumably, identification as a religious person in these societies is connected not only with the fact of expression of different religious manifestations, but with the level of intensity of such expressions as well.

Table 5

Difference Between the Share of Those Who Consider Oneself Religious And the Share of Those Who Manifest Contributors of Religious Dimensions: EVS Countries and Territories With Week Correlation Between the Religious Dimensions and Considering Oneself (Non)Religious

\begin{tabular}{|c|c|c|c|c|c|c|c|c|c|c|c|}
\hline & \multirow{2}{*}{\begin{tabular}{|c|}
$\begin{array}{c}\text { Considering } \\
\text { oneself } \\
\text { religious }\end{array}$ \\
$\%$ of resp.
\end{tabular}} & \multicolumn{2}{|c|}{$\begin{array}{c}\text { Belonging } \\
\text { (belong to } \\
\text { denomination) }\end{array}$} & \multicolumn{2}{|c|}{$\begin{array}{l}\text { Public practices } \\
\text { (attend services } \\
\text { at least several } \\
\text { times per year) }\end{array}$} & \multicolumn{2}{|c|}{$\begin{array}{c}\text { Private practices } \\
\text { (pray at least } 1 \text { a } \\
\text { month) }\end{array}$} & \multicolumn{2}{|c|}{\begin{tabular}{|} 
Experience \\
(find religion \\
important \\
or giving strength \\
and comfort)
\end{tabular}} & \multicolumn{2}{|c|}{$\begin{array}{c}\text { Faith } \\
\text { (believe in God } \\
\text { (or spirit/life } \\
\text { force) } \\
\text { or life after } \\
\text { death) }\end{array}$} \\
\hline & & $\begin{array}{l}\% \text { of } \\
\text { resp. }\end{array}$ & Diff.* & $\%$ of resp. & Diff.* & $\begin{array}{c}\% \\
\text { of resp. }\end{array}$ & Diff.* & $\begin{array}{c}\% \\
\text { of resp. }\end{array}$ & Diff.* & $\begin{array}{c}\% \\
\text { of resp. }\end{array}$ & Diff.* \\
\hline Belarus & 31.8 & 71.5 & 39.7 & 55.5 & 23.7 & 47.9 & 16.2 & 54.6 & 22.9 & 86.6 & 54.8 \\
\hline Romania & 82.9 & 98.0 & 15.1 & 78.5 & -4.3 & 85.3 & 2.4 & 79.2 & -3.7 & 97.2 & 14.4 \\
\hline Moldova & 83.3 & 93.6 & 10.3 & 86.2 & 2.9 & 85.7 & 2.4 & 87.8 & 4.5 & 96.8 & 13.5 \\
\hline
\end{tabular}

* Diff. - difference in share of responses from share of those who consider oneself religious, $\%$.

Sources: EVS 2008; a share of responses, difference in \% to the share of Religious persons, a separate analysis for each country ( $\mathrm{n} \geq 968$ per country).

Estonia and Hungary also share a certain common pattern of correlations between religiosity dimensions and considering oneself as (non)religious. In these societies, the dimensions of private practices and religious experience have a strong correlation with identification as religious, accompanied by a moderate correlation with almost all other dimensions (Table 6).

Table 6

Correlations of Considering Oneself (Non)Religious with Other Religiosity Indicators: EVS Countries and Territories with the Strong Correlation of Private Practices and Experience

\begin{tabular}{|l|c|c|c|c|c|c|}
\cline { 2 - 7 } \multicolumn{1}{c|}{} & \multicolumn{4}{c|}{ Correlation coefficient } & \multirow{2}{*}{$\begin{array}{c}\text { Considering oneself } \\
\text { religious, \% }\end{array}$} \\
\cline { 2 - 7 } \multicolumn{1}{c|}{} & $\begin{array}{c}\text { Denominational } \\
\text { identity }\end{array}$ & $\begin{array}{c}\text { Public } \\
\text { practices }\end{array}$ & $\begin{array}{c}\text { Private } \\
\text { practices }\end{array}$ & Experience & Faith & 0.55 \\
\hline Estonia & 0.61 & 0.56 & 0.69 & 0.65 & 04,4 \\
\hline Hungary & 0.55 & 0.58 & 0.68 & 0.71 & 0.54 & 53,5 \\
\hline
\end{tabular}

Sources: EVS 2008; bivariate correlations, Spearman coefficient $(\rho)$; a separate analysis for each country ( $\mathrm{n} \geq 968$ per country), all coefficients are significant at 0.01 level; the share of responses "a religious person" to question "Independently of whether you go to church or not, would you say you are...", a separate analysis for each country ( $\mathrm{n} \geq 968$ per country). 
It is important to note that, in these societies, only one in two persons considers oneself religious (44.4\% and 53.5\% for Estonia and Hungary respectively) that is significantly lower than average in the region $(75.8 \%)$, but higher than in the top 3 countries with a lowest percentage of religious people $(17.7 \%, 31.8 \%$ and $33.9 \%$ for East Germany, Belarus and Czech Republic respectively). Under such circumstances, it can be assumed that culturally constructed attributes of a religious person are not as complex as in less religious societies but they are centered on private practices and personal connection to religious life (emotions and its importance).

Moreover, the difference in the dimensions with strong correlation is observed between these countries. Unlike Hungary, where only private practice and religious experience dimensions reach a strong level of correlation, in Estonia, considering oneself (non)religion correlates highly with the denominational identity dimension. This difference might be caused by variations in the denomination structure of respective countries. In case of Hungary, the majority of population adheres to Catholicism, while in Estonia none of the big denominations includes the majority of religiously affiliated population (Table 7). The diversity of religious groups might lead to actualizing the religious affiliation factor in perceiving oneself as (non)religious.

In other societies, the share of people who consider themselves religious is closer to average for the region (Table 8). Lithuania, Ukraine, the Russian Federation, the Slovak Republic and Slovenia share a strong correlation between the Identity dimension and identification as (non)religious. Presumably, this might be related to the integration of religious affiliation and national identity. Lithuania differs from other Baltic countries in the dominance of the Catholic Church while Estonia and Latvia are countries with a multidenominational structure of adherence. Lithuania together with Slovenia (the Catholic society that stands out in the multidenominational region of former Yugoslavia) are similar in having a strong correlation between considering oneself (non)religion and denominational identity dimension as well as in showing only a moderate level of correlation between considering oneself (non)religious and all the other dimensions. This might imply that linking one's religious affiliation to one's national identity constructs the core relationship of religious self-identification. At the same time, Ukraine, the Russian Federation, the Slovak Republic are countries that constructed their identity after a long period of belonging to a more extensive and highly centralized country unions (the USSR, Czechoslovakia). Religious affiliation in these countries could serve for distinctiveness from the neighboring countries only partly (Ukraine and the Russian Federation, as the former members of the USSR, share the same dominance of the Orthodox denomination, the Slovak Republic and the Czech Republic as the former part of Czechoslovakia - the Catholic one).

Belong to a Religious Denomination: Estonia and Hungary, \%

\begin{tabular}{|l|c|c|}
\cline { 2 - 3 } \multicolumn{1}{c|}{} & Estonia & Hungary \\
\hline Roman catholic & 3.9 & 74.5 \\
\hline Protestant & 37.8 & 23.2 \\
\hline Jew & 0.4 & 0.4 \\
\hline Muslim & 0.2 & 0.0 \\
\hline Orthodox & 52.1 & 0.1 \\
\hline Other & 5.7 & 1.9 \\
\hline
\end{tabular}

Sources: EVS 2008; the share of responses among those who consider themselves belonging to a religious denomination, a separate analysis for each country (Estonia $n=511$, Hungary $n=807$ ). 
Poland, Latvia, Croatia, Bulgaria comprise a group of societies where the level of correlation of all the dimensions of religiosity to considering oneself (non)religious is of moderate intensity. What is noticeable, the societies of this group have a visible difference in the level of involvement in various types of religious manifestations. Poland's and Croatia's shares of religious affiliation and belief in God or life after death are higher, citizens of these countries more frequently attend religious services or pray and more often claim emotional connection to religion or its importance in life as compared to Latvia and Bulgaria (Table 9). Nevertheless, a common pattern of correlation between the dimensions and considering oneself (non)religious can point out that, at least hypothetically, the cultural concept of 'a religious person' in these societies doesn't require any strict adherence to particular religious manifestations or their combination.

Table 8

Correlations of Considering Oneself (Non)Religious with Other Religiosity Indicators: EVS Countries and Territories with Moderate Intensity of Correlation between Parameters

\begin{tabular}{|l|c|c|c|c|c|c|}
\hline & \multicolumn{5}{|c|}{ Correlation coefficient } & \multirow{2}{*}{$\begin{array}{c}\text { Considering } \\
\text { oneself religious, } \%\end{array}$} \\
\cline { 2 - 6 } & $\begin{array}{c}\text { Denominational } \\
\text { identity }\end{array}$ & $\begin{array}{c}\text { Public } \\
\text { practices }\end{array}$ & $\begin{array}{c}\text { Private } \\
\text { practices }\end{array}$ & Experience & Faith & \\
\hline Lithuania & 0.85 & 0.52 & 0.48 & 0.53 & 0.57 & 85,1 \\
\hline Ukraine & 0.66 & 0.41 & 0.47 & 0.56 & 0.61 & 86,6 \\
\hline The Russian Federation & 0.70 & 0.52 & 0.57 & 0.61 & 0.73 & 75,7 \\
\hline The Slovak Republic & 0.81 & 0.56 & 0.60 & 0.67 & 0.80 & 84,4 \\
\hline Slovenia & 0.62 & 0.55 & 0.55 & 0.58 & 0.52 & 72,8 \\
\hline Poland & 0.57 & 0.45 & 0.45 & 0.41 & 0.50 & 88,4 \\
\hline Latvia & 0.54 & 0.46 & 0.56 & 0.55 & 0.55 & 77,4 \\
\hline Croatia & 0.53 & 0.45 & 0.51 & 0.59 & 0.50 & 83,6 \\
\hline Bulgaria & 0.46 & 0.42 & 0.60 & 0.58 & 0.52 & 61,1 \\
\hline
\end{tabular}

Sources: EVS 2008; bivariate correlations, Spearman coefficient $(\rho)$; a separate analysis for each country ( $\mathrm{n} \geq 968$ per country), all coefficients are significant at 0.01 level; a share of responses "a religious person" to question "Independently of whether you go to church or not, would you say you are...", a separate analysis for each country ( $\mathrm{n} \geq 968$ per country).

Table 9

The Share of Those Who Consider Oneself Religious

and the Share of Those Who Manifest Contributors of Religious Dimensions: EVS Countries and Territories With Moderate Correlation Between the Religious Dimensions and Considering Oneself (Non)Religious, $\%$

\begin{tabular}{|l|c|c|c|c|c|c|}
\cline { 2 - 6 } \multicolumn{1}{c|}{} & $\begin{array}{c}\text { Considering } \\
\text { oneself } \\
\text { religious }\end{array}$ & $\begin{array}{c}\text { Denominational } \\
\text { identity } \\
\text { (belong } \\
\text { to denomination) }\end{array}$ & $\begin{array}{c}\text { Public } \\
\text { practices } \\
\text { (attend services } \\
\text { at least several } \\
\text { times per year) }\end{array}$ & $\begin{array}{c}\text { Private } \\
\text { practices } \\
\text { (pray at least } \\
\text { 1 a month) }\end{array}$ & $\begin{array}{c}\text { Experience } \\
\text { (find religion } \\
\text { important or } \\
\text { giving strength } \\
\text { and comfort) }\end{array}$ & $\begin{array}{c}\text { Faith } \\
\text { (believe in God } \\
\text { (or spirit/life } \\
\text { force) or life } \\
\text { after death) }\end{array}$ \\
\hline Poland & 88.4 & 95.5 & 89.0 & 81.2 & 75.1 & 96.0 \\
\hline Croatia & 83.6 & 84.2 & 64.9 & 66.6 & 72.2 & 92.7 \\
\hline Latvia & 77.4 & 66.3 & 43.2 & 47.1 & 31.8 & 88.5 \\
\hline Bulgaria & 61.1 & 74.6 & 62.2 & 39.3 & 55.4 & 82.6 \\
\hline
\end{tabular}

Sources: EVS 2008; a share of responses, a separate analysis for each country ( $\mathrm{n} \geq 968$ per country). 
Conclusions. Correlations between considering oneself (non)religious and the defined dimensions of religiosity - denominational Identity, practice (public and private), experience and faith - show that there are statistically significant positive correlations between these parameters in all the countries of the region included into the EVS survey. At the same time, correlation strengths differ significantly across countries. Analyzing respective differences enables us to better understand cultural specifics of various Eastern European societies and to reach a deeper level of interpretation when analyzing levels and dynamics of religiosity in respective societies. A detailed analysis of the correlation profiles allows to classify Eastern European societies into six distinct groups.

1. The group with a strong correlation between all the dimensions of religiosity and identification as religious or non-religious: East Germany and the Czech Republic. The territory and the country of this group are the least religious in the region. Considering oneself religious is tightly bound in them with every type of religious manifestation included into analysis.

2. The countries with a strong correlation of the faith sub-dimension and a moderate or weak correlation with all the other dimensions: Serbia, Albania, Bosnia-Herzegovina. The countries of this group have the highest share of religious persons in the region. The cultural model of a religious person seems to be centered on faith in these countries.

3 . The countries with a weak correlation of all the dimensions with considering oneself (non)religious: Belarus, Moldova and Romania. For these countries, religious manifestations are often declared not only by respondents who consider themselves religious but also by those who claim to be non-religious. It might imply that, in these societies, religious selfattribution requires a relatively high intensity of religious manifestation.

4. The countries with strong correlations of private practice and religious experience dimensions with considering oneself (non)religious and moderate correlations for almost all the other dimensions: Estonia and Hungary. Share of religious persons in countries of this group is significantly lower than average in the region. Presumably social understanding of 'being a religious person' is not as complex as in less religious societies but centered on private practices and personal connection to religious life.

5. The countries that have a strong correlation between denominational identity dimension and considering oneself religious and diverse correlation intensity for the other dimensions: Lithuania, Ukraine, the Russian Federation, the Slovak Republic and Slovenia. The countries of this group, share common historical background of the nations that construct their identity after a long period of belonging to more extensive and centralized country or regional unions. This might imply that linking one's religious affiliation to one's national identity constructs the core relationship of religious self-identification.

6. The countries where all the religiosity dimensions correlate moderately with considering oneself (non)religious: Poland, Latvia, Croatia, and Bulgaria. Their correlation profiles indicate that, for these countries, the cultural concept of 'a religious person' does not require strict adherence to particular religious manifestations or their combination.

The study offers working hypotheses rather than exhaustive explanations for the unveiled correlation patterns. The aforementioned differences in correlation profiles might be caused by historical and cultural background of the counties, their denominational structure and the share of persons who consider themselves religious, variations in the cultural concept of 'a religious 
Bovgyria I. V.

person' and in relations among religious and other social identities. At the same time, the results of the correlational analysis presented in this article lay foundations for further investigation. The proposed approach to the evaluation of religiosity dimensions and classification of Eastern European societies can be used as a framework for analysis of historical, cultural and socioeconomic contexts. Further research is needed to explore causalities and to develop robust explanations for the correlation patterns unveiled in this study.

\section{References}

1. Tomka, M. (2011). Expanding Religion: Religious Revival In Post-Communist Central And Eastern Europe. Berlin: Walter de Gruyter GmbH \& Co. [in English] English]

2. Davie, G. (2012). Belief and unbelief: Two sides of a coin. Approaching Religion, 2, 1, 3-7 [in

3. Küçükcan, T. (2005). Multidimensional Approach to Religion: a way of looking at religious phenomena. Journal for Study of Religion and Ideologies, 10 (Spring), 60-70 [in English]

4. Müller, O. (2012). The Social Significance of Religion in the Enlarged Europe: Secularization, Individualization and Pluralization. New York: Routledge [in English]

5. Salnikova, S.A. (2010). Constructing the content, characteristics and levels of measuring the religiosity (according to empirical sociological research). Ukr. socium [Ukrainian society], 4 (35), 108-119 [in Ukrainian]

6. Coutinho, J.P. (2016). Religiosity in Europe: an index, factors, and clusters of religiosity. Sociologia, 81, 163-188 [in English]

7. Tomka, M. (1998). Coping with Persecution: Religious Change in Communism and in PostCommunist Reconstruction in Central Europe. International Sociology, 13 (2), 229-248 [in English] English]

8. Glock, Ch. (1962). On The Study Of Religious Commitment. Religious Education, 57, 98-110 [in

9. Stark, R., Glock, Ch. (1968). American Piety: The Nature of Religious Commitment. Berkeley: University of California Press [in English]

10. King, M. (1967). Measuring the religious variable: Nine proposed dimensions. Journal for the Scientific Study of Religion, 6, 173-185 [in English]

11. Verbit, M.F. (1970). The Components and Dimensions of Religious Behavior: Toward a Reconceptualization of Religiosity. American Mosaic, Social Patterns of Religion in the United States (pp. 24-39). New York: Random House [in English]

12. O’Connell, C.M. (1975). Dimensions of Religiosity Among Catholics. Review of Religious Research, 16, 3, 198-207 [in English]

13. Integrated Dataset: European Values Study 2008. GESIS Data Archive. URL: https://dbk.gesis.org/dbksearch/sdesc2.asp?no=3811 (Last accessed: 16.04.2017)

14. Master Questionnaire: European Values Study 2008. GESIS Data Archive. URL: https://dbk.gesis.org/dbksearch/sdesc2.asp?no=381 (Last accessed: 16.04.2017)

15. Bohdanova, O.V. (2014). The level and specificity of the religiosity of European societies: are there chances for secularization theory? Visnyk Natsionalnoho tekhnichnoho universytetu Ukrainy "Kyivskyi politekhnichnyi instytut". Politolohiia. Sotsiolohiia. Pravo [Bulletin of the National Technical University of Ukraine "Kyiv Polytechnic Institute". Politology. Sociology. Law], 31-47 [in Ukrainian]

16. Yaremchuk, S.S. (2011). Study of religion in international projects of the values studies. Visnyk Natsionalnoho tekhnichnoho universytetu Ukrainy "Kyivskyi politekhnichnyi instytut". Politolohiia. Sotsiolohiia. Pravo [Bulletin of the National Technical University of Ukraine "Kyiv Polytechnic Institute". Politology. Sociology. Law], 105-108 [in Ukrainian]

17. Salnikova, S.A. (2009). Methodological principles of religiousness measurement. Naukovyi visnyk Volynskoho natsionalnoho universytetu imeni Lesi Ukrainky [Journal of Lesya Ukrainka Volyn National University], 28, 137-142 [in Ukrainian]

Received on 24.05.17 and updated on 26.06.17 
Бовгиря I.B., аспірант кафедри соціології Національного університету "Києво-Могилянська академія”, вул. Григорія Сковороди, 2, Київ, 04070, Україна, e-mail: iryna.bovgyria@gmail.com

ВИЗНАЧЕННЯ СЕБЕ (НЕ)РЕЛІГІЙНИМ(ОЮ) У СУСПІЛЬСТВАХ СХІДНОЇ ЄВРОПИ: ПАТЕРНИ КОРЕЛЯЦІЙ МІЖ ВИМІРАМИ РЕЛІГІЙНОСТІ

Використано підхід вимірів релігійності з метою оиінки того, як виміри релігійності пов'язані 3 визначенням себе релігійним(ою) у різних суспільствах Східної Свропи. Представлено порівняльний аналіз результатів Європейського дослідження иінностей (EVS) у 19 країнах Східної Європи. Результати показують, щзо для всіх суспільств регіону характерні значущі позитивні кореляції між показниками вимірів релігійності та показником самовизначення себе релігійним(ою). Проте сила зв'язку між ичими показниками від крайни до країни варіюється настільки помітно, щзо доцільніше виокремити декілька кластерів країн з подібними результатами, ніж говорити про наявність єдиної моделі зв'язку між обраними індикаторами у суспільствах Східної Свропи.

Ключові слова: релігійність, сочіологія релігії, релігія у Східній Європі, релігія у посткомуністичних суспільствах, виміри релігійності.

Бовгиря И.В., аспирант кафедры социологии Национального университета "Киево-Могилянская академия”, 04070, ул. Григория Сковороди, 2, Киев, Украина, e-mail: iryna.bovgyria@gmail.com

ОПРЕДЕЛЕНИЕ СЕБЯ (НЕ)РЕЛИГИОЗНЫМ(-ОЙ) В ОБЩЕСТВАХ ВОСТОЧНОЙ ЕВРОПЫ: ПАТТЕРНЫ КОРРЕЛЯЦИЙ МЕЖДУ ИЗМЕРЕНИЯМИ РЕЛИГИОЗНОСТИ

Использован подход измерений религиозности с иелью оценки того, насколько измерения религиозности связаны с определением себя как религиозный(ая) в разных обществах Восточной Европы. Представлен сравнительный анализ результатов Европейского исследования иенностей (EVS) в 19 странах Восточной Европь. Результаты показывают, что для всех обществ региона характерны значимые позитивные коррелячии между показателями измерений религиозности и показателем самоопределения себя как религиозный(ая). Однако сила связи между этими показателями варьируется настолько заметно от странь к стране, что целесообразнее говорить о наличии нескольких кластеров стран с подобными результатами, нежели о наличии единой модели связи между исследуемыми индикаторами в обществах Восточной Европьл.

Ключевые слова: религиозность, сочиология религии, религия в Восточной Европе, религия в посткоммунистических обществах, измерения религиозности. 